\title{
Mineral element and heavy metal (cadmium, lead and arsenic) levels of bee pollen in Turkey
}

\author{
Sema Sandikci ALTUNATMAZ, Duygu TARHAN², Filiz AKSU1², Umıt Bora BARUTÇU², Mehmet Erman OR ${ }^{3}$
}

\begin{abstract}
In this study, mineral element and heavy metal levels in bee pollen produced in various regions of Turkey (20 samples) and imported bee pollen (4 samples), were determined using an Inductively Coupled Plasma Optical Emission Spectrometry (ICP-OES) device. Mineral and heavy metal levels of bee pollens produced in Turkey were determined to be within the following ranges (minimum-maximum, $\mu \mathrm{g} / \mathrm{g}_{\text {pollen }}$ ); $\mathrm{Cr}$ (chromium): 0.124-1.595, Cu (copper): 3.728-14.994, Fe (iron): 28.603-725.360, $\mathrm{Mg}$ (magnesium): 271.107-1278.340, Mn (manganese): 8.151-201.036, Se (selenium): 0.593-5.085, Zn (zinc): 14.832-39.079, B (boron): 0.592-61.33, Ni (nickel): 0.002-1.761, Si (silicon): 0.082-10.500, K (potassium): 992.107-2894.154, Ca (calcium): 491.853-1472.102, P (phosphorus): 795.899-5246.992 and Cd (cadmium): 0.006-0.181, Pb (lead): 0.000-0.479, As (arsenic): 0.006-1.035. As a result of this study, it can be concluded that bee pollens produced in Turkey may be a good source of mineral regarding the trace elements $\mathrm{Se}, \mathrm{Mn}, \mathrm{Fe}, \mathrm{Cr}$ and $\mathrm{Cu}$.
\end{abstract}

Keywords: bee pollen; heavy metal; ICP-OES; minerals.

Practical Application: Bee pollen contains many elements necessary for life. Alongside its nutritional value, bee pollen may also contain toxic elements.

\section{Introduction}

Bee pollen is a nutrient collected from various flowering plants by bees and stored and brought to the beehive in their back legs (Dagaroglu, 2004). Bees use the pollen as the primary source of nutrition for their nourishment. It is constituted of the bee's oral secretions and some nectar. The main difference between bee pollen and flower pollen is that bee pollen is diluted with nectar, saliva and honey (Campos et al., 2008; De-Melo et al., 2015). Therefore, the mineral level in flower pollen is higher than mineral levels in bee pollen (Stanciu et al., 2011).

Bee pollen is used in apitherapy with particular emphasis placed on its antioxidant and antimicrobial properties. Its structure contains various enzymes, co-enzymes, steroids, vitamins, antibiotics, mineral substances and flavonoids (Bogdanov, 2006; Pascoal et al., 2014). 100g of bee pollen contains; 500-3000 mg mineral substances, 13-55 g carbohydrates, 10-40 g protein, 1-10 g fat, 0.3-20 g dietary fibre, 20-100 mg vitamins and 40-3000 mg flavonoid glycosides (Bogdanov, 2006). Daily mineral requirement in human nutrition has been reported as; Ca: 0.8-0.9 g, P: 0.8-1.2 g, K: 800 mg, Mg: 300-400 mg, Mn: 4-5 mg,

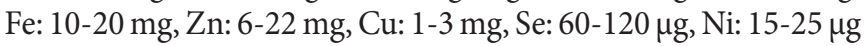
(Demirci, 2014; Tayar \& Cibik, 2011). Bee pollen is a good source of mineral for humans (Dagaroglu, 2004; Morgano et al., 2010). When pollen, propolis and honey were compared with respect to $\mathrm{Fe}, \mathrm{Zn}$ and $\mathrm{Mg}$ mineral levels, the highest ratios were reported to be found in pollen. Bee pollen has been evaluated to be rich regarding its $\mathrm{Mg}$ and $\mathrm{Zn}$ ratio, and high with respect to its $\mathrm{Fe}$ ratio (Formicki et al., 2013).

Alongside its nutritional value, bee pollen may also contain toxic elements (Bogdanov, 2006). Due to environmental contamination; heavy metals, radioactive isotopes, organic contaminants, pesticides, antibiotics and pathogenic microorganisms may be present in the air, soil, water and plants, and spread to bee pollen via these routes. Among heavy metals, $\mathrm{Pb}$ and $\mathrm{Cd}$ may have industrial origin as well as being present in the pesticide compound (Bogdanov, 2006; Campos et al., 2008). Arsenic may be present in many environmental sources such as; rocks, soil, water, dust and air. It has been reported that air and water play an important role in As contamination (Morgano et al., 2010).

It has been stated that, bee and bee products may be used as a bioindicator in determining environmental pollution and presence of heavy metals (Nispet et al., 2013). To collect pollen, bees roam an area with an average diameter of $7-13 \mathrm{~km}$ and approximately 80-100 flowers. Therefore, bees in the hive interact with approximately one million flowers (Dagaroglu, 2004; Nispet et al., 2013). For optimum pollen quality, pollen must be collected from areas at least $3 \mathrm{~km}$ away from the source of contamination (Bogdanov, 2006; Campos et al., 2008).

Turkey has an ecosystem suitable for apiculture. In Turkey, apiculture products are gaining importance due to an increasing demand for natural products as well as a long-standing apiculture 
tradition. The aim of this study is to determine mineral element and heavy metal ( $\mathrm{Pb}, \mathrm{Cd}, \mathrm{As})$ levels of bee pollens in Turkey.

\section{Materials and methods}

\subsection{Sample collection}

Bee pollen samples were collected from areas of intensive beekeeping. The samples were dried and prepared, suitable for consumption and their origins were determined via producers and sellers. Element measurements for pre-determined mineral and heavy metals were carried out in a total of 24 bee pollens. 20 of these samples were obtained from different regions of Turkey representing; the Black Sea, Central Anatolia, Eastern Anatolia, Marmara, The Mediterranean and Aegean regions. Four imported bee pollens, originating from Canada, China and Santiago and sold in Turkey, were included in the study (Table 1).

\subsection{Preparation of samples for measurement}

Pollen samples were placed into tared tubes, weighed using a precision balance and the weights recorded. $2 \mathrm{~mL}$ Nitric acid $\left(\mathrm{HNO}_{3}\right)$ was added to pollen samples placed into a heat-resistant graduated tube in a $200{ }^{\circ} \mathrm{C}$ drying oven and left to dissolve. The pollen and nitric acid mixture was left to cool at room temperature, after which $1 \mathrm{~mL}$ Perchloric acid $\left(\mathrm{HClO}_{4}\right)$ was added and the mixture was returned to the $200^{\circ} \mathrm{C}$ oven. The compound was subjected to wet ashing in the oven, vortexed and distilled water added, totaling its volume to $12 \mathrm{~mL}$. It was vortexed once more and prepared for element analysis in the ICP-OES device.

\subsection{Element measurement}

Suitable wavelengths of 267.716, 324.754, 259.940, 285.213, 257.610, 196.090, 206.200, 189.042, 249.773, 221.647, 251.611, $228.802,220.353,766.490,317.933$ and $177.495 \mathrm{~nm}$ were used for the analysis of $\mathrm{Cr}, \mathrm{Cu}, \mathrm{Fe}, \mathrm{Mg}, \mathrm{Mn}, \mathrm{Se}, \mathrm{Zn}, \mathrm{As}, \mathrm{B}, \mathrm{Ni}, \mathrm{Si}, \mathrm{Cd}, \mathrm{Pb}$, $\mathrm{K}, \mathrm{Ca}, \mathrm{P}$ elements respectively in the ICP-OES device (Thermo iCAP 6000 series). Samples were subjected to wet ashing and prepared for measurement. Four samples from each pollen type were prepared and mean values of the element analysis results

Table 1. Regional distribution of bee pollen samples.

\begin{tabular}{ccc}
\hline Region/ county & City & Sample no. of Pollen \\
\hline Black Sea & Artvin-Kaçkar & $6-9-11$ \\
Marmara Region & Çanakkale & $20-21-22$ \\
& Bursa & 19 \\
Yalova & $1-7-10-12$ \\
Aegean Region & Izmit & 15 \\
Eastern Anatolia & Sivas, Erzurum & 13 \\
Central Anatolia & Kayseri & 2 \\
The Mediterranean & Mersin & $5-23$ \\
Region & & $18-8-17$ \\
China & Santiago & $14-16$ \\
Chile & & 24 \\
Canada & & 24 \\
Total & & \\
\hline
\end{tabular}

were calculated. The stock solution was prepared from standard solutions containing $\mathrm{Cr}, \mathrm{Cu}, \mathrm{Fe}, \mathrm{Mg}, \mathrm{Mn}, \mathrm{Se}, \mathrm{Zn}, \mathrm{As}, \mathrm{B}, \mathrm{Ni}, \mathrm{Si}$, $\mathrm{Cd}, \mathrm{Pb}, \mathrm{K}$, Ca ve $\mathrm{P}$ (Chem-Lab NV) and distilled water was used for the blank solution. The calibration graph was obtained from the ICP-OES device using blank and standard solutions and element concentration measurements of the prepared pollen samples were carried out. The measurements were repeated 4 times and mean values were determined.

\section{Results}

Minimum and maximum values $\left(\mu \mathrm{g} / \mathrm{g}_{\text {pollen }}\right)$ of all analyses performed for each element in pollens in Turkey (20) were determined as; Cr: 0.075-1.912, Cu: 3.621-26.578, Fe: 22.848-1183.173, Mg: 258.246-1705.036, Mn: 7.401-237.695, Se: 0.520-6.617, Zn: 14.442-53.120, B: 0.558-74.316, Ni: 0.001-1.937, Si: 0.030-15.675, K: 711.458-3123.664, Ca: 378.407-2140.741, P: 229.8795-6095.05, Cd: $0.000-0.215, \mathrm{~Pb}: 0.000-1.383$, As: 0.004-1.304. Mineral element and heavy metal mean values of bee pollens are shown in Tables 2-5.

Daily mineral requirement rates were calculated based on the $25 \mathrm{~g} /$ day consumption of bee pollens produced in Turkey. According to Brazilian legislation, mineral requirements of; Ca: 1000 mg/day, Fe: 14 mg/day, Cu: $900 \mu \mathrm{g} /$ day, Cr: 35 gg/day, Mn: 2.3 mg/day, P: 700 mg/day, Zn: 7 mg/day and Mg: 260 mg/day, Se: $0.034 \mathrm{mg} /$ day and K: $4700 \mathrm{mg} /$ day for women and men aged between 19-30 years, were taken into account. Based on this data, bee pollens produced in Turkey supply daily mineral requirement at the following rates: $\mathrm{K}: 1 \%, \mathrm{Mg}: 6 \%$, Se: $46 \%$, Cu: $28 \%$, Fe: $36 \%$, Mn:32\%, Zn: 10\%, Cr: 36\%, Ca: $2 \%$, P: $9 \%$.

\section{Discussion}

Within the scope of this research, similarities or varying degrees of differences between mineral levels and the regions from which the bee pollens originated can be seen in all the bee pollens. In 3 bee pollens obtained from plants of different origin (colour differences) in the city of Çanakkale, while some mineral values were very close, differences between the Fe $(55.333,168.449)$, Mn $(11.605,54.628)$ and $\mathrm{Ca}(493.998,954.493)$ values were interesting. In this study, it was concluded that similarities as well as differences may be present in mineral levels of bee pollens obtained from the same city. These differences or similarities in mineral levels are related to factors such as; flower varieties from which the bee pollen was collected, climate conditions, geography, environmental conditions, genetic composition of the plant species, agricultural procedures (fertilization and agricultural spraying) and apicultural processes (Bonhevi \& Jorda, 1997; Dagaroglu, 2004; Dinkov \& Stratev, 2016; Feas et al., 2012; Harmanescu et al., 2007; Nispet et al., 2013). It has been stated that, mineral levels are related to plant type rather than the soil and geographical situation. It has been expressed that, some of the minerals in bee pollen are of nectar origin (Kostic et al., 2015). Turkey has regional (Bursa, Çanakkale etc) Boron reserves. The fact that Boron levels are generally high in bee pollen obtained from regions and surrounding areas where Boron reserves are high suggests that soil type is also important. Changes in mineral levels of bee pollens in relation to many factors may cause difficulties regarding a standard product. 
Table 2. Mineral element and heavy metal mean values $\left(\mu \mathrm{g} / \mathrm{g}_{\text {pollen }}\right)$ of bee pollens produced in Turkey.

\begin{tabular}{|c|c|c|c|c|c|c|c|c|c|c|c|c|}
\hline No & $\mathrm{Cr}$ & $\mathrm{Cu}$ & $\mathrm{Fe}$ & $\mathrm{Mn}$ & $\mathrm{Se}$ & $\mathrm{Zn}$ & $\mathrm{B}$ & $\mathrm{Ni}$ & $\mathrm{Si}$ & $\mathrm{Cd}$ & $\mathrm{Pb}$ & As \\
\hline 1 & 0.536 & 11.157 & 140.223 & 19.456 & 3.912 & 37.813 & 0.946 & 0.004 & 0.261 & 0.113 & 0.176 & 0.015 \\
\hline 2 & 1.159 & 14.994 & 340.117 & 201.036 & 5.085 & 39.079 & 0.799 & 0.020 & 0.082 & 0.086 & 0.088 & 0.010 \\
\hline 4 & 0.337 & 10.616 & 313.532 & 19.713 & 3.242 & 30.387 & 0.693 & 0.007 & 0.132 & 0.040 & 0.055 & 0.009 \\
\hline 5 & 0.912 & 7.062 & 60.691 & 30.652 & 1.845 & 27.272 & 34.850 & 1.062 & 7.249 & 0.070 & 0.222 & 0.446 \\
\hline 6 & 0.730 & 11.622 & 510.235 & 25.087 & 2.127 & 23.873 & 0.841 & 0.005 & 0.110 & 0.061 & 0.304 & 0.009 \\
\hline 7 & 0.842 & 11.398 & 725.360 & 18.295 & 2.154 & 27.738 & 0.700 & 0.002 & 0.142 & 0.046 & 0.278 & 0.008 \\
\hline 10 & 0.644 & 13.907 & 168.662 & 17.874 & 2.572 & 31.217 & 0.708 & 0.002 & 0.195 & 0.042 & 0.102 & 0.007 \\
\hline 11 & 0.777 & 12.734 & 290.442 & 17.745 & 1.863 & 24.892 & 0.592 & 0.008 & 0.098 & 0.095 & 0.390 & 0.006 \\
\hline 12 & 0.589 & 10.611 & 182.455 & 16.047 & 2.120 & 26.895 & 0.650 & 0.003 & 0.245 & 0.047 & 0.479 & 0.010 \\
\hline 13 & 0.246 & 3.728 & 28.603 & 8.151 & 0.593 & 14.832 & 34.220 & 0.690 & 6.014 & 0.058 & 0.000 & 0.406 \\
\hline 15 & 0.506 & 9.465 & 95.763 & 15.127 & 2.076 & 28.372 & 0.708 & 0.002 & 0.198 & 0.033 & 0.215 & 0.010 \\
\hline 17 & 0.124 & 4.808 & 30.719 & 9.311 & 1.295 & 15.160 & 51.640 & 0.943 & 1.982 & 0.113 & 0.000 & 0.759 \\
\hline 18 & 1.595 & 12.688 & 107.525 & 21.918 & 2.990 & 34.365 & 61.330 & 0.736 & 10.500 & 0.051 & 0.117 & 0.983 \\
\hline 19 & 1.169 & 9.005 & 78.794 & 19.353 & 2.956 & 30.572 & 56.790 & 1.090 & 8.490 & 0.006 & 0.145 & 1.035 \\
\hline 20 & 1.218 & 7.471 & 55.333 & 11.605 & 2.813 & 32.647 & 34.440 & 0.642 & 2.189 & 0.181 & 0.212 & 0.871 \\
\hline 21 & 0.911 & 9.641 & 168.449 & 54.627 & 3.228 & 33.381 & 46.920 & 1.761 & 6.024 & 0.054 & 0.296 & 0.907 \\
\hline 22 & 0.788 & 7.879 & 113.805 & 13.826 & 2.954 & 22.026 & 33.600 & 1.202 & 6.112 & 0.095 & 0.182 & 1.011 \\
\hline 23 & 1.016 & 13.040 & 118.107 & 19.796 & 3.488 & 33.245 & 36.380 & 0.861 & 3.869 & 0.025 & 0.231 & 0.873 \\
\hline Mean & 0.793 & 10.418 & 203.165 & 29.329 & 2.560 & 29.153 & 22.298 & 0.512 & 3.220 & 0.069 & 0.193 & 0.391 \\
\hline
\end{tabular}

Table 3. $\mathrm{K}, \mathrm{Mg}$, $\mathrm{Ca}, \mathrm{P}$ mean values $\left(\mu \mathrm{g} / \mathrm{g}_{\text {pollen }}\right)$ of bee pollens produced in Turkey.

\begin{tabular}{crrrr}
\hline No & \multicolumn{1}{c}{$\mathrm{K}$} & \multicolumn{1}{c}{$\mathrm{Mg}$} & \multicolumn{1}{c}{$\mathrm{Ca}$} & \multicolumn{1}{c}{$\mathrm{P}$} \\
\hline 1 & 1811.094 & 919.343 & 580.278 & 865.879 \\
2 & 2485.519 & 1200.501 & 491.853 & 795.899 \\
4 & 2702.758 & 814.476 & 679.514 & 1331.377 \\
5 & 1796.641 & 419.090 & 785.355 & 3518.333 \\
6 & 2365.266 & 1278.340 & 1016.559 & 1786.657 \\
7 & 2099.323 & 987.505 & 878.967 & 1191.741 \\
8 & 2671.459 & 613.053 & 1227.646 & 4721.593 \\
9 & 2165.239 & 721.926 & 764.602 & 1819.231 \\
10 & 1699.761 & 949.572 & 920.300 & 1541.382 \\
11 & 2004.736 & 593.459 & 847.933 & 1361.374 \\
12 & 1664.247 & 633.786 & 902.981 & 1335.985 \\
13 & 2224.814 & 271.106 & 1472.102 & 5246.992 \\
15 & 1453.998 & 617.565 & 677.717 & 1045.813 \\
17 & 1619.484 & 316.023 & 1019.669 & 4055.672 \\
18 & 2894.154 & 720.719 & 1177.349 & 4714.479 \\
19 & 1539.838 & 641.464 & 936.270 & 3839.639 \\
20 & 1681.628 & 333.048 & 493.997 & 3301.834 \\
21 & 1604.919 & 412.245 & 954.493 & 3363.309 \\
22 & 1440.419 & 383.981 & 631.935 & 3147.411 \\
23 & 992.107 & 568.204 & 789.182 & 4210.083 \\
Mean & 1945.87 & 669.770 & 862.435 & 2659.730 \\
\hline & & & &
\end{tabular}

It is thought that, the control of human related factors such as, environmental pollution and apicultural procedures, may prevent differences, particularly with respect to heavy metals. In fact, in one study, Dinkov \& Stratev (2016) expressed that there were no major differences between regions regarding $\mathrm{Cd}$ and $\mathrm{Pb}$ levels in bee pollens. It has also been stressed that, by the bee's feeding on heavy metal-containing nutrients, such as sugar, heavy metal contamination may also be present in bee products (Dinkov \& Stratev, 2016).

In this study, amounts of mineral elements in one gram are arranged from greatest to smallest as; $\mathrm{P}, \mathrm{K}, \mathrm{Ca}, \mathrm{Mg}, \mathrm{Fe}, \mathrm{Mn}, \mathrm{Zn}$, $\mathrm{B}, \mathrm{Cu}, \mathrm{Se}, \mathrm{Si}, \mathrm{Cr}, \mathrm{Ni}$. In some studies, the most common mineral element is reported to be $\mathrm{K}$ (Campos et al., 2008; Morgano et al., 2012; Szczesna, 2007). Despite changes in amounts depending on the type of mineral element in bee pollen, it has been reported that the mineral content of bee pollen is $\mathrm{K} 60 \%, \mathrm{Mg} 20 \%$, $\mathrm{Na}$ and $\mathrm{Ca}$ 10\% (Campos et al., 2008). In 27 bee pollens collected in Poland, South Korea and China, mineral elements were reported to be arranged as $\mathrm{K}>\mathrm{Mg}>\mathrm{Na}>\mathrm{Ca}>\mathrm{Fe}>\mathrm{Mn}>\mathrm{Zn}>\mathrm{Cu}$ (Szczesna, 2007). In another study, this line up was $\mathrm{K}>\mathrm{P}>\mathrm{Ca}>\mathrm{Mg}>\mathrm{Na}>\mathrm{Fe}>\mathrm{Mn}$ $>\mathrm{Zn}>\mathrm{Cu}$ (Morgano, et al., 2012). In 25 bee pollens investigated in a study in Serbia, K: 2462-4236, Ca: 856-2032, Mg: 503-964, Fe: 39.56-141.29, Zn: 28.76-75.92, Mn: 13.52-92.23 mg/kg values were determined and the bee pollens were reported to be very rich with respect to $\mathrm{Fe}$ and $\mathrm{Zn}$, while most commonly found were $\mathrm{K}, \mathrm{Ca}$ and $\mathrm{Mg}$ (Kostic et al., 2015). When compared to the results of this study, in bee pollens produced in Turkey, $\mathrm{Ca}, \mathrm{K}$ and $\mathrm{Zn}$ values were found to be lower, while $\mathrm{Fe}, \mathrm{Mg}$ and $M n$ values were higher. The mineral element $P$ was found to be more common in bee pollens produced in Turkey.

In a study carried out in Poland, South Korea and China (27 bee pollens, $\mathrm{mg} / \mathrm{kg}$ ), the following high values were determined; Poland, Ca: 542-1080 and Cu: 5.6-23.9, China Mn: 13.2-429.8, Mg: 1126-1893, K: 4247-5976, South Korea, Zn: 23.7-60.7 and Fe: 74.3-365.9 (Szczesna, 2007). In bee pollens produced in Turkey, while the $\mathrm{Ca}$ value is higher, $\mathrm{Cu}, \mathrm{K}, \mathrm{Fe}$, $\mathrm{Mg}, \mathrm{Mn}$ and $\mathrm{Zn}$ values were found to be lower. In this study, 
Table 4. Mineral element and heavy metal mean values $\left(\mu \mathrm{g} / \mathrm{g}_{\text {pollen }}\right)$ of imported bee pollens.

\begin{tabular}{ccrrrrrrrrrrrr}
\hline $\mathrm{No}$ & $\mathrm{Cr}$ & $\mathrm{Cu}$ & $\mathrm{Fe}$ & $\mathrm{Mn}$ & $\mathrm{Se}$ & $\mathrm{Zn}$ & $\mathrm{B}$ & $\mathrm{Ni}$ & $\mathrm{Si}$ & $\mathrm{Cd}$ & $\mathrm{Pb}$ & $\mathrm{As}$ \\
\hline 3 & 0.480 & 19.191 & 306.675 & 33.957 & 4.237 & 41.679 & 0.618 & 0.009 & 0.053 & 0.077 & 0.000 & 0.008 \\
14 & 0.373 & 4.977 & 103.294 & 9.479 & 0.644 & 17.479 & 39.820 & 0.418 & 14.120 & 0.046 & 0.000 & 0.279 \\
16 & 0.298 & 5.077 & 50.056 & 10.743 & 1.482 & 14.805 & 58.470 & 0.580 & 5.192 & 0.081 & 0.004 & 0.668 \\
24 & 0.726 & 7.170 & 96.770 & 29.470 & 3.236 & 31.101 & 41.730 & 1.305 & 2.004 & 0.044 & 0.339 & 1.054 \\
\hline
\end{tabular}

$\mathrm{Mn}, \mathrm{Mg}$ and $\mathrm{K}$ levels in bee pollens from China were seen to be lower than those in the present research (Tables 4, 5). In another study carried out in China, levels of P: 5946, K: 5324, Ca: 2068, Mg: 1449, Fe: 119.3, Mn: 70.23, Zn: 45.10, Cu: 17.35 mg/kg were determined in bee pollens (Yang et al., 2013). In comparison with the mentioned study, the Fe level determined in the present study was seen to be higher, while $\mathrm{P}, \mathrm{K}, \mathrm{Ca}, \mathrm{Mg}, \mathrm{Mn}, \mathrm{Cu}$ and $\mathrm{Zn}$ levels were lower, and that the $\mathrm{Zn}$ level in bee pollen from China was similar. The Fe level determined in the present study was found to be higher than the 26.1-92.0, 3.61-8.41, 1.24-2.49, 1.07-1.69 $\mu \mathrm{g} / \mathrm{g}$ values determined by Formicki et al. (2013) in regions of Southern Poland and the Fe: 40.14-88.7 ppm value determined by Harmanescu et al. (2007). In 8 different bee pollens collected from various regions in Romania, $\mathrm{Cu}: 5.51-12.07 \mathrm{ppm}$, $\mathrm{Zn}: 33.93-54.35 \mathrm{ppm}$ and $\mathrm{Mn}: 12.78-98.25 \mathrm{ppm}$ was determined (Harmanescu et al., 2007). It can be seen that, in the mineral levels in bee pollens produced in Turkey, the $\mathrm{Cu}$ value is similar, the $\mathrm{Mn}$ value is higher and the $\mathrm{Zn}$ value is lower (Table 4). Concentration of the mineral substances were evaluated in terms of $\mathrm{mg} / \mathrm{kg}$ where values were; Fe: 11.1-80.3, Ca: 252.9-850, Zn: 18.8-81.1, K: 2485-6411, Cu: 4.1-15.7, Mg: 273-815.7, P: 294.7-854.4, Mn: 7.4-8.3 and 20 bee pollens were evaluated (Bonhevi \& Jorda, 1997). When compared to the present study, $\mathrm{Fe}, \mathrm{Ca}, \mathrm{Cu}, \mathrm{Mg}, \mathrm{P}$ and $\mathrm{Mn}$ values were found to be higher, while $\mathrm{Zn}$ and $\mathrm{K}$ values were found to be lower (Tables 2-5).

Mineral substance mean values $\left(\mu \mathrm{g} / \mathrm{g}_{\text {pollen }}\right)$ for bee pollens produced in Turkey were determined to be; K: 1945.870, Ca: 862.435, Mg: 669.769, Fe: 203.165, Cu: 10.418, Mn: 29.33, Zn: 29.153, Se: 2.560 , P: 2659.73. In 154 bee pollen samples collected from different regions in Brazil, values were; K: 5089, Ca: 2215, Mg: 1179, Fe: 82, Cu: 9.6, Mn: 64, Zn: 46.7, Se 0.51, P: $4828 \mathrm{mg} / \mathrm{kg}$. It has been reported that K, P, Ca and $\mathrm{Mg}$ are major mineral elements in pollen and that $\mathrm{Mn}$ and Se are rich sources for Brazilian pollen, while $\mathrm{Cu}, \mathrm{P}$ and $\mathrm{Zn}$ may be a source (Morgano et al., 2012). When mean values were compared, $\mathrm{Cu}$, $\mathrm{Fe}, \mathrm{Mn}$ and Se values were found to be higher in the present study, while $\mathrm{Zn}, \mathrm{K}, \mathrm{Mg}$, Ca and $\mathrm{P}$ values were seen to be lower. It can be said that, bee pollens produced in Turkey may be a rich source of Se and $\mathrm{Mn}$ minerals, while also a source of $\mathrm{Ca}$. In another study carried out in 5 bee pollens in Brazil, mineral substance mean values $(\mathrm{mg} / 100 \mathrm{~g})$ were determined as; Ca: 68.9, Fe: 13.4, Cu: 0.87, Cr: 1.0, Mn: 4.0, P: 480, Zn: 3.5. In view of the results obtained in the present study, $\mathrm{Ca}, \mathrm{Fe}$ and $\mathrm{Cu}$ levels were high and $\mathrm{Cr}, \mathrm{Mn}, \mathrm{P}$ and $\mathrm{Zn}$ levels were low. According to legislative regulations in Brazil, depending on its mineral content, food is described as "source food" if RDI values $>15 \%$ and "high content food" if RDI $>30 \%$. In the study carried out for bee pollens in Brazil, bee pollen was classed as "high content food" depending on its essential elements $\mathrm{Fe}, \mathrm{Cr}$ and
Table 5. K, Mg, Ca and P mean values ( $\left.\mu \mathrm{g} / \mathrm{g}_{\mathrm{pollen}}\right)$ of imported bee pollens.

\begin{tabular}{ccrrr}
\hline No & \multicolumn{1}{c}{$\mathrm{K}$} & \multicolumn{1}{c}{$\mathrm{Mg}$} & \multicolumn{1}{c}{$\mathrm{Ca}$} & \multicolumn{1}{c}{$\mathrm{P}$} \\
\hline 3 & 2471.018 & 1111.973 & 680.061 & 1043.708 \\
14 & 2414.352 & 359.290 & 1296.739 & 3383.856 \\
16 & 2726.714 & 561.295 & 1634.456 & 4694.666 \\
24 & 1300.233 & 410.638 & 514.942 & 3064.424 \\
\hline
\end{tabular}

Mn (Sattler et al., 2016). In the light of the data obtained in this study, bee pollen can be evaluated as "high content food" with respect to $\mathrm{Se}(46 \%), \mathrm{Fe}(36 \%), \mathrm{Cr}(36 \%), \mathrm{Mn}(32 \%)$ and "source food" regarding $\mathrm{Cu}(28 \%)$.

In this study, Ni level was determined to be $0.002-1.761 \mu \mathrm{g} / \mathrm{g}_{\text {pollen }}$. In their studies, Morgano et al. (2010) and Harmanescu et al. (2007) determined $\mathrm{Ni}$ level to be $<0.10-1.13 \mathrm{mg} / \mathrm{kg}$ and 0-0.72 ppm, respectively. The results found in the present study were higher than these values, however, lower than the result found by Formicki et al. (2013) (Ni: 3.61-8.41 $\mu \mathrm{g} / \mathrm{g}$ ). According to Brazilian legislation, Maximum Tolerable Limit (MTL) has been determined as $5 \mathrm{mg} / \mathrm{kg}$ for $\mathrm{Ni}$. In glucose metabolism, Cr plays a role together with insulin (Harmanescu et al., 2007; Mertz, 1981). According to Polish standards, Cr must not exceed $0.14 \mathrm{mg} / \mathrm{kg}$ (Roman, 2007; Roman et al., 2016). In one study, Cr was seen to be the most problematic element and $50 \%$ of the samples exceeded the limit value $(0.14 \mathrm{mg} / \mathrm{kg}$ ) (Roman et al., 2016). In the 20 bee pollens produced in Turkey, examined in this study, Cr value was determined to be below the $0.14 \mathrm{mg} / \mathrm{kg}$ value in only one sample. In the research carried out in Southwest Poland, Cr was determined as $0.138 \mathrm{mg} / \mathrm{kg}$ (Roman et al., 2016). In Brazil, Sattler et al. (2016) determined the recommended daily intake (RDI) for $\mathrm{Cr}$ as $35 \mu \mathrm{g}$. In this case, the $\mathrm{Cr}$ level found in this study supplies $36 \%$ of daily requirement (Sattler et al., 2016). For adults, the safe and sufficient $\mathrm{Cr}$ value has also been reported as 50-200 $\mu \mathrm{g}$ (Mertz, 1981). Differences in national standards and the lack of international standards cause difficulties in the assessment of bee pollens with respect to minerals. The mineral elements B and Si analysed in this study, had not been widely researched in previous bee pollen studies.

The heavy metal levels $\left(\mu \mathrm{g} / \mathrm{g}_{\text {pollen }}\right)$ of the analysed bee pollens were; $\mathrm{Pb}: 0.000-0.479$, Cd: 0.006-0.181, As: 0.006-1.035, and Pb: 0.000-0.339, Cd: 0.044-0.081, As: 0.008-1.054 in imported bee pollens. It has been reported that, the heavy metal content in bee pollen should not exceed the amounts of; Cd: $0.03 \mathrm{mg} / \mathrm{kg}$, $\mathrm{Pb}: 0.5 \mathrm{mg} / \mathrm{kg}$, As: $0.5 \mathrm{mg} / \mathrm{kg}$ (Campos et al., 2008). In the light of this criteria, when all bee pollens in this study were assessed, it was observed that; As level had exceeded the limit in 8 bee pollens, Cd level had met these values in only 2 Turkish bee pollens and that $\mathrm{Pb}$ value had remained under the limit in all bee pollens. According to Polish standards, the following limits 
must not be exceeded; Cd: 0.05, Pb: 0.50 and As: $0.20 \mathrm{mg} / \mathrm{kg}$ (Roman, 2007; Roman et al., 2016). With regard to this standard, As value exceeded the limit in 13 and Cd value in 15 bee pollens in the present study.

Results of the research with respect to heavy metal ratio were evaluated. In the investigation carried out on bee pollens collected from Southwest Brazil over a period of 1 year; As: $<0.01-1.38 \mathrm{mg} / \mathrm{kg}$, Cd: 0.003-0.233 mg/kg, $\mathrm{Pb}:<0.01-0.44 \mathrm{mg} / \mathrm{kg}$ was determined (Morgano et al., 2010). In another study performed in Bulgaria, in 8 dried bee pollens, the highest and lowest $\mathrm{Pb}$ and $\mathrm{Cd}$ levels were determined to be $0.45-0.494$ and $0.019-0.030 \mathrm{mg} / \mathrm{kg}$, respectively (Dinkov \& Stratev, 2016). In Southern Poland, depending on the regions, $\mathrm{Cd}$ and $\mathrm{Pb}$ levels in bee pollens were found to be 26.1-92.0 and 1.24-2.49 $\mu \mathrm{g} / \mathrm{g}$ (Formicki et al., 2013). In 29 fresh bee pollens from midwest Opolo (years 2005-2006), Pb: 0.910-0.490, Cd: 0.239-0.265, As: 0.069- 0.025 mg/kg levels were determined (Roman, 2007). In a study carried out in 36 bee pollens collected from two separate parts of the Opolo region in the same years, $\mathrm{Pb}$ : 0.491-0.804, Cd: 0.234-0.272, As: $0.036-0.060$ levels were reported (Roman, 2009). In a study investigating 25 pollen samples from Southwest Poland; As: 0.325, $\mathrm{Pb}$ : 0.093, Cd: $0.019 \mathrm{mg} / \mathrm{kg}$ levels were found (Roman et al., 2016). The highest heavy metal levels in the present study were determined as; Pb: 0.479, Cd: 0.181, As: 1.054.

Considering heavy metals can spread with environmental pollution via soil, water and air, environmental steps must be taken to prevent it reaching dangerous levels for health.

\section{Conclusion}

This study suggests that bee pollens produced in Turkey may be assessed as a good source of mineral regarding the trace elements $\mathrm{Se}, \mathrm{Mn}, \mathrm{Fe}, \mathrm{Cr}$ and $\mathrm{Cu}$, in particular. When compared to other studies, the $\mathrm{Zn}$ level was found to be lower. The lack of international limits to determine bee pollen quality, as well as differences in national standards, causes difficulties in assessment. In recent times, bee pollen has become a frontline product due to increased interest and consumer demand for natural products. Both its use in apitherapy and its components renders it important. Considering the fact that bee pollen may be consumed by children, elderly people and pregnant women, both producers and consumers should be cautious with respect to heavy.

\section{Acknowledgements}

This work was supported by Istanbul University, Faculty of Veterinary Medicine (VET-BH-16-8). The authors thanks to Dr. Defne Joan Sadalak Mckinstry for help during the study.

\section{References}

Bogdanov, S. (2006). Contaminants of bee products. Apidologia, 37(1), 1-18. http://dx.doi.org/10.1051/apido:2005043.

Bonhevi, S. J., \& Jorda, E. J. (1997). Nutrient composition and microbiological quality of honeybee-collected pollen in Spain. Agriultural Food Chemistry, 4, 725-732.
Campos, M. G. R., Bogdanov, S., Almeida-Muradian, L. B., Szczesna, T., Mancebo, Y., Frigerio, C., \& Ferreira, F. (2008). Pollen composition and standardisation of analytical methods. Journal of Apicultural Research and Bee World, 47(2), 154-161. http://dx.doi.org/10.1080 /00218839.2008.11101443.

Dagaroglu, M. (2004). Modern beekeeping techniques (chap. 14, 2nd ed.). Tekirdağ: Doga Arıcılık Tic.

De-Melo, A. A. M., Estevinho, M. L. M. F., \& Almeida-Muradian, L. B. (2015). A diagnosis of the microbiological quality of dehydrated bee-pollen produced in Brazil. Letters in Applied Microbiology, 61(5), 477-483. PMid:26280091. http://dx.doi.org/10.1111/lam.12480.

Demirci, M. (2014). Food chemical. (7th ed., pp. 148-156). Istanbul: Hat.

Dinkov, D., \& Stratev, D. (2016). The content of two toxic heavy metals in Bulgarian bee pollen. International Food Research Journal, 23(3), 1343-1345.

Feas, X., Vazquez-Tato, M. P., Estevinho, L., Seijas, J. A., \& Iglesias, A. (2012). Organic bee pollen: Botanical origin, nutritional value, bioactive compounds, antioxidant activity and microbiological quality. Molecules, 17, 8359-8377. http://dx.doi.org/10.3390/ molecules 17078359 .

Formicki, G., Gren, A., Stawarz, R., Zysk, B., \& Gal, A. (2013). Metal content in honey, propolis, wax and bee pollen and implications for metal pollution monitoring. Polish Journal of Environmental Studies, 22(1), 99-106.

Harmanescu, M., Bordean, D., \& Gergen, I. (2007). Heavy metals content of bee's pollen from different locations of Romania. Lucrari Stiintifice: Medicina Veterinara, 40, 253-260.

Kostic, A. Z., Pesic, M. B., Mosic, M. D., Dojcinovic, B. P., Natic, M. M., \& Trifkovic, J. D. (2015). Mineral content of bee pollen from Serbia. Arhiv za Higijenu Rada i Toksikologiju, 66(4), 251-258. PMid:26751856. http://dx.doi.org/10.1515/aiht-2015-66-2630.

Mertz, W. (1981). The essential trace elements. Science, 213(4514), 1332 1338. PMid:7022654. http://dx.doi.org/10.1126/science.7022654.

Morgano, M. A., Martin M. C. T., Rabonato, L. C., Milani, R. F., Yatsuyanagi, K., \& Rodriguez-Amaya, D. B. (2012). A Comprehensive investigation of the mineral composition of Brazillian bee pollen: geographic and seasonal variations and contribution to human diet. Journal of the Brazilian Chemical Society, 23(4), 727-736.

Morgano, M. A., Martins, M. C. T., Rabonato, L. C., Milani, R. F., Yotsuyanagi, K., \& Rodriguez-Amaya, D. B. (2010). Inorganic bee pollens from Southeastern Brazil. Journal of Agricultural and Food Chemistry, 58(11), 6876-6883. PMid:20450185. http://dx.doi. org/10.1021/jf100433p.

Nispet, C., Guler, A., Yarim, G. F., \& Ardali, Y. (2013). Relationship between environmental and flora change with mineralk content of honey bee products. Turkish Journal of Biochemistry, 38(4), 494-498. http://dx.doi.org/10.5505/tjb.2013.07269.

Pascoal, A., Rodrigues, S., Teixeira, A., Feas, X., \& Estevinho, L. M. (2014). Biological activities of commercial bee pollens: antimicrobial, antimutagenic, antioxidant and anti-inflammatory. Food and Chemical Toxicology, 63, 233-239. PMid:24262487. http://dx.doi. org/10.1016/j.fct.2013.11.010.

Roman, A. (2007). Content of some trace elements in fresh honeybee pollen. Polish Journal Of Food And Nutrition Sciences, 57(4C), 475-478.

Roman, A. (2009). Concentration of chosen trace elements of toxic properties in bee pollen loads. Polish Journal of Environmental Studies, 18(2), 265-272.

Roman, A., Popiela-Pleban, E., Migdat, P., \& Kruszynski, W. (2016). As, $\mathrm{Cr}, \mathrm{Cd}$, and bee product from a polish industrialized region. Open Chemichal, 14, 33-36. 
Sattler, O. A. G., De-Melo, A. A. M., Nascimento, K. S., Melo, I. L. P., Mancini-Filho, J., Sattler, A., \& Almeida-Muradian, I. B. (2016). Essential minerals and inorganic contaminants (barium, cadmium, lithium, lead and vanadium) in dried bee pollen produced in Rio Grande do Sul State, Brazil. Food Science and Technology (Campinas), 36(3), 505-509. Retrieved from http://www.scielo. br/scielo.php?pid=S0101-20612016005012103\&script=sci_arttext

Stanciu, O. G., Margithas, L. A., Dezmirean, D., \& Campos, M. G. (2011). A comparison between the mineral content of flower and honeybee collected pollen of selected plant origin (Heliantus annuus L. and Salix sp.). Romanian Biotechnological Letters, 16(4), 6291-6295.

Szczesna, T. (2007). Concentration of selected elements in honeybeecollected pollen. The Journal of Agricultural Science, 51(1), 5-13.

Tayar, M., \& Cibik, R. (2011). Food chemical. (2nd ed., pp. 157-178). Bursa: Dora.

Yang, K., Wu, D., Ye, X., Liu, D., Chen, J., \& Sun, P. (2013). Characterization of chemical compozisition of bee pollen in China. Journal of Agricultural and Food Chemistry, 61(3), 708-718. PMid:23265625. http://dx.doi.org/10.1021/jf304056b. 